\title{
Synthesis and mechanical properties of a calcium sulphoaluminate cement made of industrial wastes
}

\author{
M. Gallardoø, J.M. Almanza, D.A. Cortés, J.C. Escobedo, J.I. Escalante-García \\ CINVESTAV (Ramos Arizpe, Coah, México) \\ $\triangle$ marisol.gallardoh@gmail.com
}

Received 13 June 2013

Accepted 13 November 2013

Available on line 18 September 2014

\begin{abstract}
Environmentally-friendly calcium sulphoaluminate clinkers were obtained from a mixture of aluminium dross, fluorgypsum, fly ash and $\mathrm{CaCO}_{3}$ at temperatures within the range of 1100 to $1400{ }^{\circ} \mathrm{C}$. After the heat treatments $\mathrm{Ca}_{4} \mathrm{Al}_{6} \mathrm{O}_{12} \mathrm{SO}_{4}$ was the main phase. Three different cements were prepared using the clinkers synthesized at 1250,1350 and $1400{ }^{\circ} \mathrm{C}$; the clinker powders were mixed with $20 \mathrm{wt} \%$ of hemihydrate. Cement pastes were prepared using a water/cement ratio (w/c), 0.4 followed by curing at 20 or $40{ }^{\circ} \mathrm{C}$ for periods of time ranging from 1 to 28 days. Most of the samples showed high compression strengths 40-47 MPa after 28 days, which were comparable to the strength of Portland cement. Ettringite was the main hydration product and its morphology consisted of acicular and hexagonal plates, which is typical of this phase.
\end{abstract}

KEYWORDS: Clinker; Calcium Sulpholuminate; Wastes; Ettringite

Citation / Citar como: Gallardo, M.; Almanza, J.M.; Cortés, D.A.; Escobedo, J.C.; Escalante, J.I. (2014) Synthesis and mechanical properties of a calcium sulphoaluminate cement made of industrial wastes. Mater. Construcc. 64 [315], e023 http://dx.doi.org/10.3989/mc.2014.04513.

RESUMEN: Síntesis y propiedades mecánicas de un cemento de sulfoaluminato de calcio hecho de residuos industriales. Se fabricaron clinkers de bajo impacto ambiental a base de sulfoaluminato de calcio calcinando mezclas de escoria de aluminio, fluoryeso, ceniza volante y $\mathrm{CaCO}_{3}$ a diferentes temperaturas dentro de un rango de 1100 a $1400{ }^{\circ} \mathrm{C}$. Se observó la formación de $\mathrm{Ca}_{4} \mathrm{Al}_{6} \mathrm{O}_{12} \mathrm{SO}_{4}$ como fase principal. Para obtener los cementos, los clinkers obtenidos a 1250,1350 y $1400{ }^{\circ} \mathrm{C}$ se mezclaron con $20 \%$ en peso de hemihidrato. Se prepararon pastas usando una relación agua/cemento, de 0.4 y se curaron a 20 y $40{ }^{\circ} \mathrm{C}$ por diferentes periodos de tiempo desde 1 hasta 28 días. Los valores de resistencia a la compresión a los 28 días de curado de la mayoría de las muestras estuvieron entre 40-47 MPa, equiparables a los de referencia de pastas de cemento Portland. La etringita fue el principal producto de hidratación y su morfología consistió de placas hexagonales y aciculares, típicas de esta fase.

PALABRAS CLAVE: Clinker; Sulfoaluminato de calcio; Desechos; Etringita

Copyright: (C) 2014 CSIC. This is an open-access article distributed under the terms of the Creative Commons Attribution-Non Commercial (by-nc) Spain 3.0 License.

\section{INTRODUCTION}

Aluminum scrap recycling generates important amounts of dross, which forms on the surface of the aluminum liquid bath. There are several methods for the treatment of this byproduct and most of them focus on the recovering of metallic aluminum; its composition varies depending on the purification procedure, in general, it may contain $\mathrm{Al}_{2} \mathrm{O}_{3}, \mathrm{AlN}$, $\mathrm{Al}_{4} \mathrm{C}_{3}, \mathrm{SiO}_{2}, \mathrm{MgO}, \mathrm{Al}$ and minor quantities of $\mathrm{Si}$, $\mathrm{Fe}$ and $\mathrm{Mg}$. Many small aluminum recycling companies do not treat the generated aluminum dross 
and it is usually confined in landscapes in incandescent state allowing the metallic aluminum to oxidize, therefore this kind of byproduct has a high alumina content (1) . Aluminum dross has been used in several applications, such as reinforcing material in aluminum-dross composites (2) synthesis of spinel (3) by solid-state reaction with $\mathrm{MgO}$, synthesis of SiAlON (4) and carbothermal reduction and nitridation process, as raw material for the preparation of refractory (5), manufacture of calcium aluminate cement (6) synthesis of $\mathrm{Mg}-\mathrm{Al}, \mathrm{Ca}-\mathrm{Al}$ and $\mathrm{Zn}-\mathrm{Al}$ type $\mathrm{LDH}_{\mathrm{S}}(7)$ using $\mathrm{HCl}$ and $\mathrm{NaOH}$ solutions. The high amount of alumina in the dross makes this waste a suitable material for the synthesis of several kinds of ceramics, in particular as a raw material for the synthesis of some cements.

Nowadays, the cementitious material most used worldwide is the Portland cement and its demand increases with the population growth. Nonetheless, its production involves the generation of great amount of $\mathrm{CO}_{2}$ emissions, i.e, about $0.85-1.00$ tons of $\mathrm{CO}_{2}$ are produced for each ton of clinker $(8,9)$. In 2011 the global compsumption of Portland cement clinker was of $2.7 \mathrm{Gt}$ which contributes to the generation of about $7 \%$ of total $\mathrm{CO}_{2}$ emissions worldwide $(10,11)$. As the cement demand continues to grow, it is necessary to develop alternative low environmental impact binders able to attain mechanical properties similar or superior to those of Portland cement (12). One alternative is the calcium sulphoaluminate cements (Ye'elemite or $\mathrm{C}_{4} \mathrm{~A}_{3} \bar{S}$ ), which is the core of this work.

A typical clinker of $\mathrm{C}_{4} \mathrm{~A}_{3} \bar{S}$ contains $50-70 \mathrm{wt} \%$ of ye'elemite, 5-20 wt \% of belite $\left(\mathrm{C}_{2} \mathrm{~S}\right), 5-20 \mathrm{wt} \%$ of ferrite $\left(\mathrm{C}_{4} \mathrm{AF}\right)$ and $3-10 \mathrm{wt} \%$ of mayenite $\left(\mathrm{Ca}_{12} \mathrm{Al}_{14} \mathrm{O}_{33}\right)$ (13). Ye'elemite and mayenite are responsible of the early setting of the cement, while belite shows a slow hydration contributing to the final strength to the cement (14). The ground clinker is usually mixed with $20-30 \mathrm{wt}^{\mathrm{O}} \%$ of gypsum to prepare the cement. Calcium sulphoaluminate is usually obtained from mixtures of $\mathrm{CaCO}_{3}, \mathrm{Al}_{2} \mathrm{O}_{3}$ and $\mathrm{CaSO}_{4} \cdot 2 \mathrm{H}_{2} \mathrm{O}$ and the firing temperature leads to lower $\mathrm{CO}_{2}$ generation compared to the Portland cement manufacture; the total energy required for its manufacture $(1.337 \mathrm{~kJ} / \mathrm{kg})$ is also lower compared to Portland cement $(1.756 \mathrm{~kJ} / \mathrm{kg})(15,16)$. The ye'elemite clinker is also highly porous and this implies a reduction in production costs (17). $\mathrm{C}_{4} \mathrm{~A}_{3} \bar{S}$ shows low alcalinity, suitable mechanical properties, appropriate stability in sea water $(18,19)$, can be used to for stabilizing dangerous wastes and fixation of heavy metals (20-22) and they are resistant to carbonation (23). The ye'elemite clinker has been also used as a partial or total substitute of CPO in order to reduce shrinkage and reduce setting time in special applications (24). The mechanical strength of mortars (containing commercial clinker, $20 \mathrm{wt}^{\circ} \%$ gypsum and cured at $20^{\circ} \mathrm{C}$ ) reached
$42 \mathrm{MPa}$ after one year (16). A study on mortars of $\mathrm{C}_{4} \mathrm{~A}_{3} \bar{S}$ with $19 \mathrm{wt}^{\mathrm{0}} \%$ of gypsum, reported the use of fillers of quartz and $\mathrm{CaCO}_{3}$; the latter increased the hydration rate and decreased the setting time reaching compressive strength up to $34 \mathrm{MPa}$ after 28 days of curing at $20^{\circ} \mathrm{C}(25)$. Garcia-Mate et al. (26) found that mortars of $\mathrm{C}_{4} \mathrm{~A}_{3} \bar{S}$ with an addition of $10 \mathrm{wt} \%$ of gypsum had 7 day strengths higher than a mortar containing $30 \mathrm{wt} \%$ gypsum; however, this situation inverted when a superplasticizer was added. Pastes containing alite-calcium sulphoaluminate $\left(50 \mathrm{wt}^{\%} \%\right)-\operatorname{slag}\left(30 \mathrm{wt}^{0} \%\right)$-limestone $(20 \mathrm{wt} \%)$ developed a compressive strength of $90 \mathrm{MPa}$ after 90 days of curing (27). One of the main characteristics of these cements is the formation of expansive ettringite, which is the result of the hydration process in presence of gypsum (28-31).

The source of the main components of several kinds of cements is mainly natural raw materials such as clays, alumina and $\mathrm{CaCO}_{3}$ and can be synthetized at temperatures between 1300 $1350{ }^{\circ} \mathrm{C}$; however the formation of $\mathrm{C}_{4} \mathrm{~A}_{3} \bar{S}$ has been reported from $1100-1325{ }^{\circ} \mathrm{C}$ (14), becoming stable from $1350-1400{ }^{\circ} \mathrm{C}$ (32). Several types of industrial wastes can be used as raw materials to obtain the $\mathrm{Ca}$ sulphoaluminte clinker. $\mathrm{Wu}$ et al. obtained a clinker of $\mathrm{C}_{4} \mathrm{~A}_{3} \bar{S}$ from a mixture of Municipal Solid Incineration Wastes-Limestonebauxite-gypsum at $1250{ }^{\circ} \mathrm{C}$, reaching more than 73.2 MPa after 28 days of curing (33). Li et al. (34) obtained a clinker by firing a mixture of fly ash, bauxite and calcium carbonate at $1300{ }^{\circ} \mathrm{C}$. Li et al. (35) obtained the clinker at a temperature as low as $1150{ }^{\circ} \mathrm{C}$ using fly ash and sludge as raw materials. Singh et al. $(36,37)$ reported the formation of a ferric calcium sulphoaluminate from a mixture of $\mathrm{CaO}$, red mud and bauxite at $1250{ }^{\circ} \mathrm{C}$, as well as using waste from a fertilizer industry, bauxite and iron mineral ore at $1250{ }^{\circ} \mathrm{C}$. In general, these works showed the feasibility to obtain a calcium sulphoalumninate clinker using several industrial wastes as raw materials. However, there is a great variety of industrial wastes that have the potential to be used as a source of the main components to fabricate this kind of cement. This work shows the feasibility of producing calcium sulphoaluminate clinkers from a mixture of aluminum dross, fluorgypsum and fly ash; the mechanical and microstructural characterization of the cements was carried out.

\section{EXPERIMENTAL}

The composition of raw materials used for the synthesis of all of the calcium sulphoaluminate clinkers was of $45.53 \mathrm{wt} \%$ of aluminum dross (AD), $12.82 \mathrm{wt}^{\circ} \%$ of fluorgypsum (FG), $0.64 \mathrm{wt}^{\circ} \%$ of fly ash (FA) and $41 \mathrm{wt}^{\%} \mathrm{CaCO}_{3}$. The raw materials were ball milled until obtaining particle sizes smaller than $106 \mu \mathrm{m}$ (\#140 ASTM mesh). Each raw material 
was chemically analyzed by X-ray fluorescence specstroscopy (XRF, Table 1). Based on this chemical analysis a mixture was designed so as to obtain $80 \mathrm{wt} \%$ of calcium sulphoaluminate $\left(\mathrm{Ca}_{4} \mathrm{Al}_{6} \mathrm{O}_{12} \mathrm{SO}_{4}\right)$ and $20 \mathrm{wt} \%$ of belite. Disk pellets of $4 \mathrm{~cm}$ in diameter were uniaxially pressed at $45 \mathrm{MPa}$. Samples were heat treated at different temperatures from 1100 to $1400{ }^{\circ} \mathrm{C}$ at intervals of $50{ }^{\circ} \mathrm{C}$ for $4 \mathrm{~h}$ at a heating rate of $10{ }^{\circ} \mathrm{C} / \mathrm{min}$. Soaking for 4 hours was selected in order to reach thermodynamic stability. The samples were then analyzed by X-ray diffraction (XRD).

The clinker samples obtained at 1250, 1350 and $1400{ }^{\circ} \mathrm{C}$ were selected based on the results obtained by XRD. In order to prepare the cements, samples were ball milled until obtaining a specific surface area of about $3800 \mathrm{~cm}^{2} / \mathrm{g}$ (Blaine, ASTM C-204) (38) and then mixed with $20 \mathrm{wt} \%$ of commercial hemihydrate $\left(\mathrm{CaSO}_{4} \cdot 1 / 2 \mathrm{H}_{2} \mathrm{O}\right)$. The cement pastes were prepared by mixing the cements with water using water to cement ratio (w/c) of 0.4 . Samples were cast in nylamid molds and cured at 20 and $40^{\circ} \mathrm{C}$ for up to 28 days. A Portland cement paste was also prepared as reference and cured at $20^{\circ} \mathrm{C}$; this reached $43.7 \mathrm{MPa}$ after 28 days of curing at $20{ }^{\circ} \mathrm{C}$. The setting time was determined using the procedure indicated in the ASTM-191 (39). The compressive strength was evaluated after 1, 3, 7, 14 and 28 days of curing, reporting the average of 4 samples. Fragments from the compressive essay were immersed in methanol in order to stop any further hydration. The fragments were then dried in a vacuum stove at $30^{\circ} \mathrm{C}$ and then analyzed by X-ray Diffraction (XRD). The fracture surface of the samples was observed by scanning electron microscopy (SEM).

\section{RESULTS AND DISCUSSION}

The formation of $\mathrm{Ca}_{4} \mathrm{Al}_{6} \mathrm{O}_{12} \mathrm{SO}_{4}$ was detected by XRD analyses (Figure 1) in the samples treated at temperature as low as $1100{ }^{\circ} \mathrm{C}$ and it

TABle 1. Chemical composition of raw materials

\begin{tabular}{lcccc}
\hline Oxides & $\begin{array}{c}\text { Aluminum } \\
\text { dross }(\mathbf{w t} \%)\end{array}$ & $\begin{array}{c}\text { Fly ash } \\
(\mathbf{w t} \%)\end{array}$ & $\begin{array}{c}\text { Fluorgypsum } \\
(\mathbf{w t} \%)\end{array}$ & $\begin{array}{c}\mathbf{C a C O}_{3} \\
(\mathbf{w t} \%)\end{array}$ \\
\hline $\mathbf{N a}_{2} \mathbf{O}$ & 2.496 & - & - & - \\
$\mathbf{M g O}$ & 5.043 & 1.377 & - & 0.03 \\
$\mathbf{A l}_{2} \mathbf{O}_{3}$ & 63.19 & 24.81 & - & 0.03 \\
$\mathrm{SiO}_{2}$ & 11.61 & 59.49 & 0.103 & - \\
$\mathbf{S O}_{3}$ & 0.833 & - & 56.33 & - \\
$\mathbf{C l}$ & 4.636 & - & - & - \\
$\mathbf{K}_{2} \mathbf{O}$ & 2.203 & 1.716 & - & - \\
$\mathbf{C a O}$ & 7.263 & 4.806 & 43.24 & - \\
$\mathrm{TiO}_{2}$ & 0.983 & 1.663 & - & - \\
$\mathbf{M n O}$ & 0.503 & - & - & - \\
$\mathbf{F e}_{2} \mathbf{O}_{3}$ & 1.203 & 6.126 & - & 0.029 \\
$\mathbf{C a C O}_{3}$ & - & - & - & 97.07 \\
\hline
\end{tabular}

was present even in the samples treated at $1400{ }^{\circ} \mathrm{C}$ in a lower quantity; the decreased intensity of the main reflection was attributed the thermodynamic instability of this compound at high temperatures. The formation of $\mathrm{Ca}_{4} \mathrm{Al}_{6} \mathrm{O}_{12} \mathrm{SO}_{4}$ is in agreement with previous reports that indicated the formation of ye'elemite at $1150{ }^{\circ} \mathrm{C}$ by using other industrial wastes (15). The formation of secondary phases depends on the sources of raw materials, in this case the other main phase detected was gehlenite $\left(\mathrm{Ca}_{2} \mathrm{~A}_{2} \mathrm{SiO}_{7}\right)$. The anhydrite was detected until $1200{ }^{\circ} \mathrm{C}$, which indicated that the reaction to form $\mathrm{Ca}_{4} \mathrm{Al}_{6} \mathrm{O}_{12} \mathrm{SO}_{4}$ was still not complete at these low temperatures. Merwinite $\left(\mathrm{Ca}_{3} \mathrm{Mg}\left(\mathrm{SiO}_{4}\right)_{2}\right)$ was detected at temperatures between 1100 and $1150{ }^{\circ} \mathrm{C}$, which is an unstable phase that reacted with alumina at higher temperatures to form gehlenite $\left(\mathrm{Ca}_{2} \mathrm{Al}_{2} \mathrm{SiO}_{7}\right)$, which has been reported in this kind of commercial cements in as much as $15 \%(40)$. The spinel phase was present in the samples treated at all the temperatures, indicating its stability when aluminum dross is as a raw material. Above $1250{ }^{\circ} \mathrm{C}$ the peaks corresponding to calcium aluminate $\left(\mathrm{CaAl}_{2} \mathrm{O}_{4}\right)$, mayenite $\left(\mathrm{Ca}_{12} \mathrm{~A}_{14} \mathrm{O}_{33}\right)$, belite $\left(\mathrm{Ca}_{2} \mathrm{SiO}_{4}\right)$ and pleochroite $\left(\mathrm{Ca}_{20} \mathrm{Al}_{26} \mathrm{Mg}_{3} \mathrm{Si}_{3} \mathrm{O}_{68}\right)$ were also detected. Calcium sulphoaluminate, belite, mayenite and calcium aluminate are considered cementitious phases, the latter forms from the decomposition of $\mathrm{C}_{4} \mathrm{~A}_{3} \bar{S}$ which it becomes unstable above $1350{ }^{\circ} \mathrm{C}$. On the other hand, phases such as gehlenite, spinel and pleochroite have poor hydraulic properties, however they may act as a reinforcing phases.

In Table 2 the setting times for each cement are reported. The system A1 showed the longest setting times compared to systems A2 and A3. The initial and final setting times decreased as the synthesis temperature increased, this occurred because at higher temperatures the samples contained lower amounts of the main cementive phase, $\mathrm{Ca}_{4} \mathrm{Al}_{6} \mathrm{O}_{12} \mathrm{SO}_{4}$. At 1350 and $1400{ }^{\circ} \mathrm{C}$ the quantity of the main cementive phase decreased and when taking into account that the amount of hemihydrate and the w/c ratio were the same for all the systems used, there were more water and gypsum available to form ettringite and therefore the hydration reactions occurred at higher velocities.

Figure 2 shows the compressive strength for the systems A1, A2 and A3 after 1, 3, 7, 14 and 28 days of curing at 20 or $40^{\circ} \mathrm{C}$.

The system A1 cured at $20^{\circ} \mathrm{C}$ showed a strength loss of $3 \mathrm{MPa}$ at 14 days due to the delayed ettringite formation, that involves a volume change and some crack formation. This was corroborated by XRD analysis which showed the presence of $\mathrm{C}_{4} \mathrm{~A}_{3}$ after 1 day and its absence from 7 days onwards, together with more intense peaks of Ettringite. The strength of A1 increased to $41 \mathrm{MPa}$ at 28 days since 


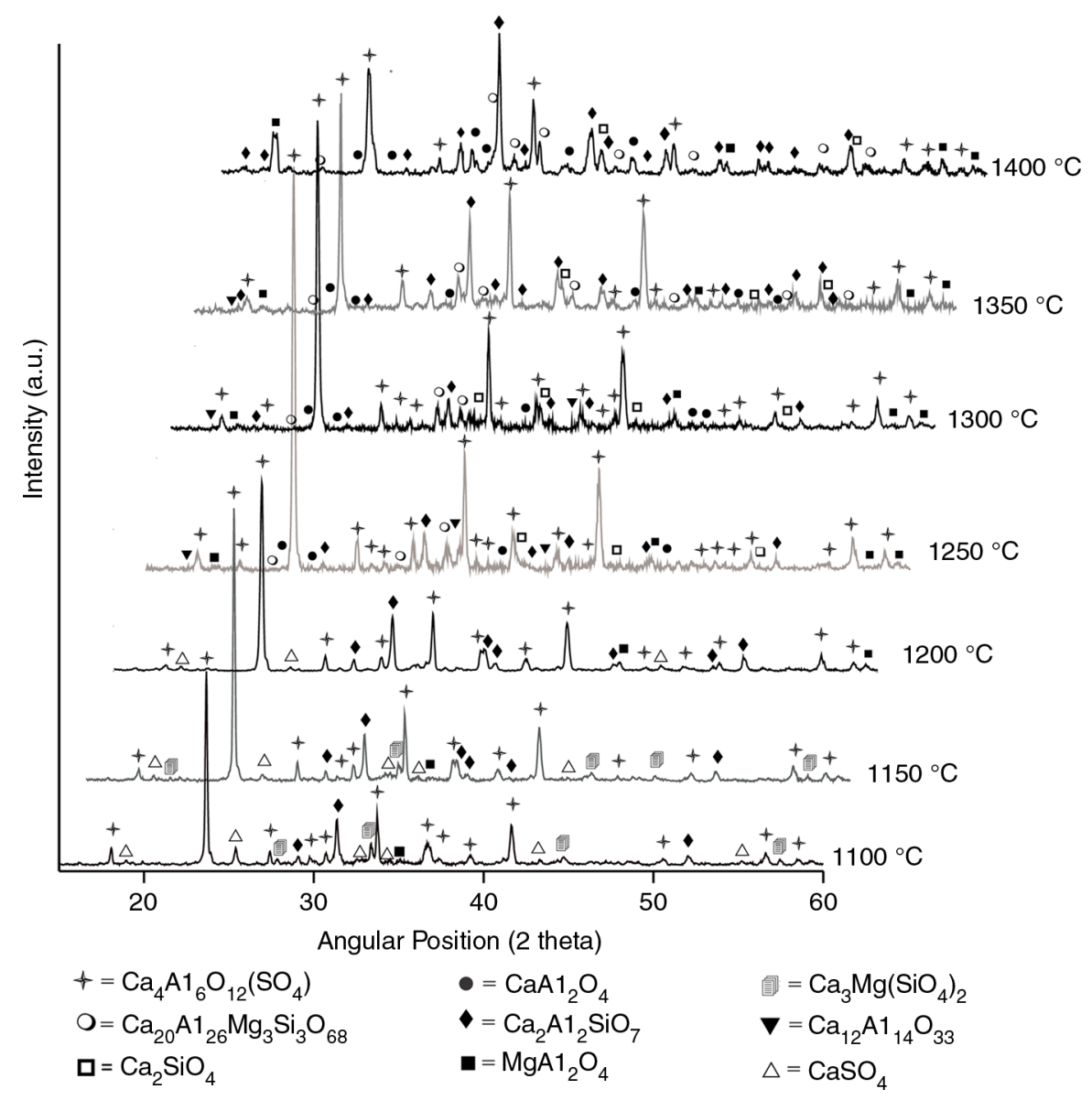

FIGURE 1. XRD patterns of the heat treated mixture $\left(1100\right.$ to $\left.1400{ }^{\circ} \mathrm{C}\right)$.

TABLE 2. Setting times of the cements obtained

\begin{tabular}{lcccccc}
\hline System & $\begin{array}{c}\text { Synthesis } \\
\text { temperature }\left({ }^{\circ} \mathbf{C}\right)\end{array}$ & $\begin{array}{c}\text { Thermal } \\
\text { treatment time (h) }\end{array}$ & Ratio w/c & Hemihydrate wt $\%$ & $\begin{array}{c}\text { Initial setting } \\
\text { time (min) }\end{array}$ & $\begin{array}{c}\text { Final setting } \\
\text { time (min) }\end{array}$ \\
\hline A1 & 1250 & $4 \mathrm{~h}$ & 0.4 & 20 & 28 & 46 \\
A2 & 1350 & $4 \mathrm{~h}$ & 0.4 & 20 & 23 & 37 \\
A3 & 1400 & $4 \mathrm{~h}$ & 0.4 & 20 & 16 & 30 \\
\hline
\end{tabular}

$\mathrm{A} 1, \mathrm{~A} 2, \mathrm{~A} 3$ have the same composition with $45.53 \mathrm{wt} \%$ of $\mathrm{AD}, 12.82 \mathrm{wt} \%$ of $\mathrm{FY}, 0.65 \mathrm{wt} \%$ of $\mathrm{FA}$ and $41 \mathrm{wt} \%$ of $\mathrm{CaCO}_{3}$.

ettringite continued to grow in the cracks previously formed. The system A2 also showed a decrease in strength at 7 days caused by the delayed ettringite formation followed by an increase up to $43 \mathrm{MPa}$ at 28 days. For the system A3, a continuos increase in strength from day 1 was observed, reaching 41 $\mathrm{MPa}$ at 28 days of curing, this indicates that the majority of the Ettringite formed during the first hours of setting. For the systems cured at $40{ }^{\circ} \mathrm{C}$, sample A1 showed a decrease in strength of about $13 \mathrm{MPa}$ at 7 days of curing, followed by an increase up to $43 \mathrm{MPa}$ at 28 days, reaching $47 \mathrm{MPa}$. As the curing temperature increased, a higher rate of ettringite growth was observed forming crystal of larger size, leading to the formation of cracks in the microstructure. The system A3 cured at $40{ }^{\circ} \mathrm{C}$ showed a slight strength loss of about $4 \mathrm{MPa}$ at 14 days, then it reached $43 \mathrm{MPa}$ at 28 days. The systems cured at 20 and $40{ }^{\circ} \mathrm{C}$ reached strengths above $40 \mathrm{MPa}$ at 28 days of curing. These were lower than those of $59 \mathrm{MPa}$ reported by Singh et al. (36) for a calcium sulphoaluminate cement obtained from waste materials and close to those reported by Xin et al. (41) of $47 \mathrm{MPa}$ in pastes 


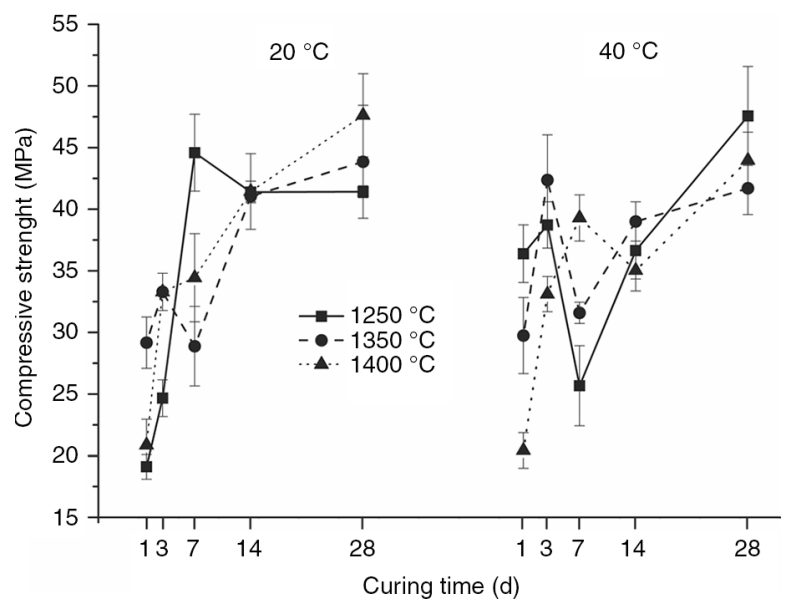

Figure 2. Compressive strength of the systems $\mathrm{A} 1\left(1250^{\circ} \mathrm{C}\right)$, A2 $\left(1350{ }^{\circ} \mathrm{C}\right)$ and $\mathrm{A} 3\left(1400^{\circ} \mathrm{C}\right)$ cured for 1,3 ,

7,14 and 28 days at 20 or $40^{\circ} \mathrm{C}$.

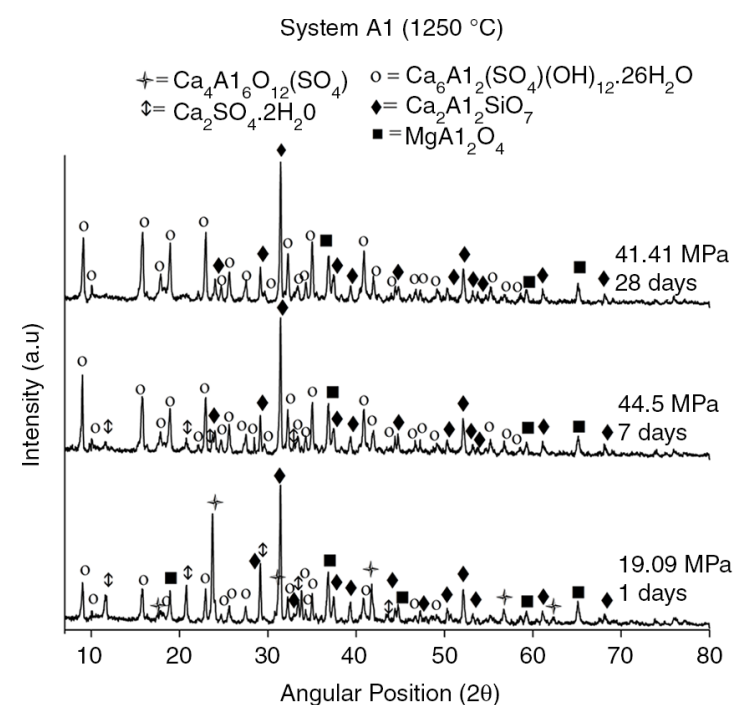

of calcium sulphoaluminate cement produced by using reagent grade chemicals.

Figure 3 shows the XRD patterns for the systems A1, A2 and A3 cured for 1,7 and 28 days at $20^{\circ} \mathrm{C}$.

After 1 day, the main phase present in the system A1 was the calcium sulphoaluminate, which indicated that the reaction was not completed. The reflections corresponding to ettringite $\left(\mathrm{Ca}_{6} \mathrm{Al}_{2}\left(\mathrm{SO}_{4}\right)_{3}(\mathrm{OH})_{12} 26 \mathrm{H}_{2} \mathrm{O}\right)$ indicated that it formed by a rapid dissolution of the calcium sulphoaluminate phase releasing $\mathrm{Al}^{3+}, \mathrm{Ca}^{2+}$ and $\mathrm{SO}_{4}{ }^{2-}$ ions, which play an important role in the formation of the hydrate crystals. As the curing time increased the peaks corresponding to ettringite increased, the presence of gypsum at 7 days indicated that the reaction of ettringite formation was still not complete. Spinel was noted at all studied curing times since it is inert and do not form any hydrates. For the system A2

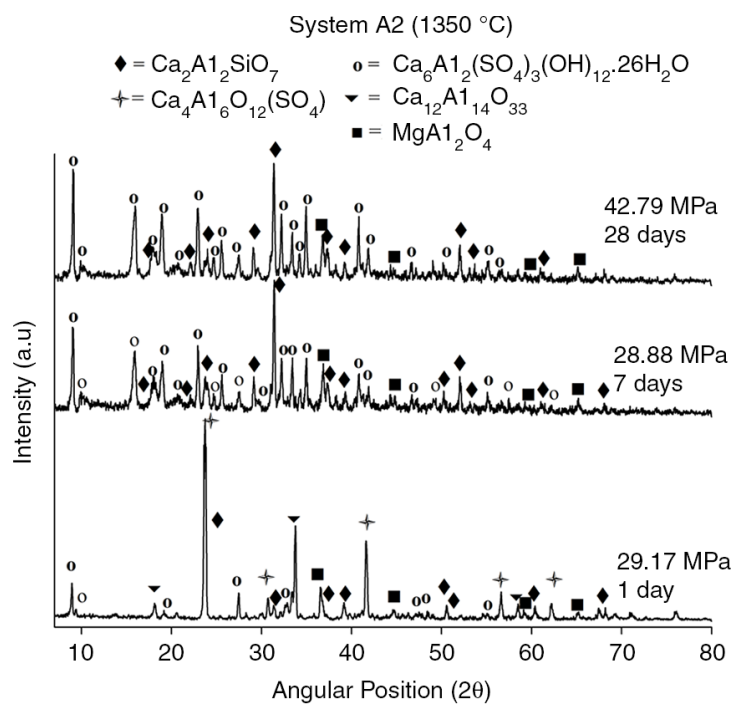

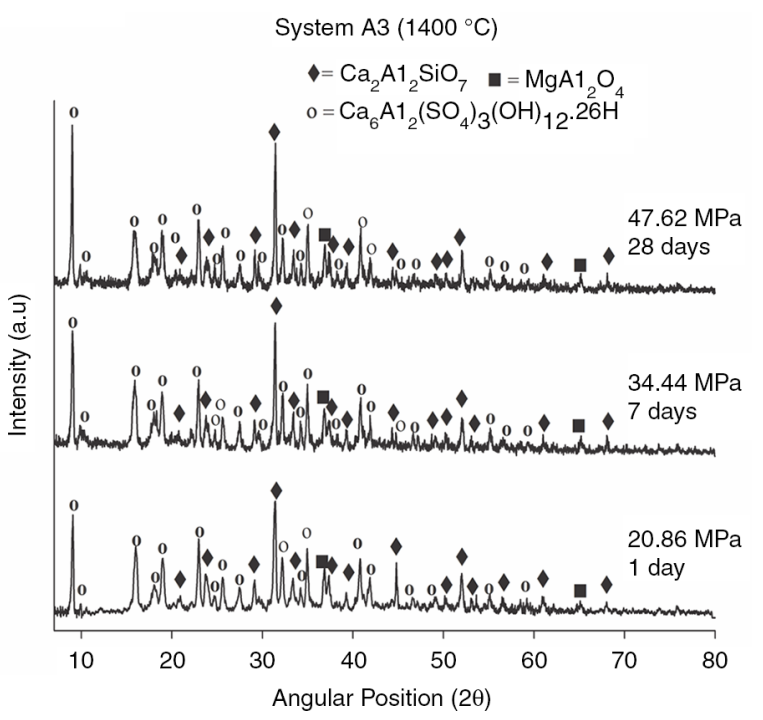

FIGURE 3. XRD patterns of the systems A1, A2 y A3 cured for 1,7 y 28 days at $20^{\circ} \mathrm{C}$. 
at 1 day of curing the main phase detected was $\mathrm{Ca}_{4} \mathrm{Al}_{6} \mathrm{O}_{12} \mathrm{SO}_{4}$ and, in minor amounts, $\mathrm{Ca}_{2} \mathrm{Al}_{2} \mathrm{SiO}_{7}$, $\mathrm{Ca}_{12} \mathrm{Al}_{14} \mathrm{O}_{33}$ and $\mathrm{Ca}_{6} \mathrm{Al}_{2}\left(\mathrm{SO}_{4}\right)_{3}(\mathrm{OH})_{12} \cdot 26 \mathrm{H}_{2} \mathrm{O}$. After 7 days the peaks corresponding to ettringite increased in intensity and no significant changes were evident after 28 days.

For system A3, the main phase detected from 1 day and at any other curing time was Ettringite, indicating its formation since the early stages. As discussed above, for A3 there were lower amounts of the main cementive phase, which means that more hemihydrate and water are available to form ettringite than in the case of the A1 and A2 systems. Under these conditions, sulphoaluminate reacts rapidly forming the hydrates. A fairly similar behavior was observed for the systems cured at $40^{\circ} \mathrm{C}$.

Figure 4 shows the microstructure images obtained by SEM for the systems A1, A2 and A3 cured for 1,7 and 28 days at $20{ }^{\circ} \mathrm{C}$. The systems $\mathrm{A} 1$ and $\mathrm{A} 2$ showed after 1 day of curing a compact morphology; as curing time advanced, the growing of ettringite needles and the formation of microcracks were observed. Since ettringite continued forming, the cracks were eventually filled by such phase and therefore the microstructure appeared compact after 28 days of curing, which was consistent with the increased compressive strength after 28 days. On the other hand, for sample A3 there were no evident microstructural changes during the studied times; the formation of ettringite since the early curing times resulted in a compact structure from as early as day 1 .
Figure 5 shows the fracture SEM images corresponding to the A3 system cured for 1, 14 and 28 days at 20 or $40{ }^{\circ} \mathrm{C}$. A strength loss was noted after 14 days of curing for $40^{\circ} \mathrm{C}$ (A31440).) for this system. The ettringite crystals formed at $40^{\circ} \mathrm{C}$ were larger than those present after curing at $20{ }^{\circ} \mathrm{C}$ (A31420). The non-homogeneous growth of these crystals created voids and cracks leading to a decrease in strength.

Samples cured at $40{ }^{\circ} \mathrm{C}$ showed the formation of plackets leading to a less dense microstructure at 1 and 14 days in comparison with samples cured at $20^{\circ} \mathrm{C}$. In both samples cured at 20 and $40{ }^{\circ} \mathrm{C}$ ettringite continued growing filling the cracks previously formed, which in turn favored increased 28 days strengths.

\section{CONCLUSIONS}

- Environmentally friendly and high compressive strength calcium sulphoaluminate cements were developed (up to $47 \mathrm{MPa}$, similar to Portland cement).

- The formation of $\mathrm{Ca}_{4} \mathrm{Al}_{6} \mathrm{O}_{12} \mathrm{SO}_{4}$ was achieved at temperatures as low as $1100^{\circ} \mathrm{C}$. The amount of this phase increased at $1250{ }^{\circ} \mathrm{C}$ and then becomes unstable at temperatures above this temperature.

- Ettringite was the main hydration product. The systems synthesized at lower temperatures showed a decrease in strength at 7 days and/or 14 days of curing due to the delayed ettringite formation, which generates the formation of microcracks.

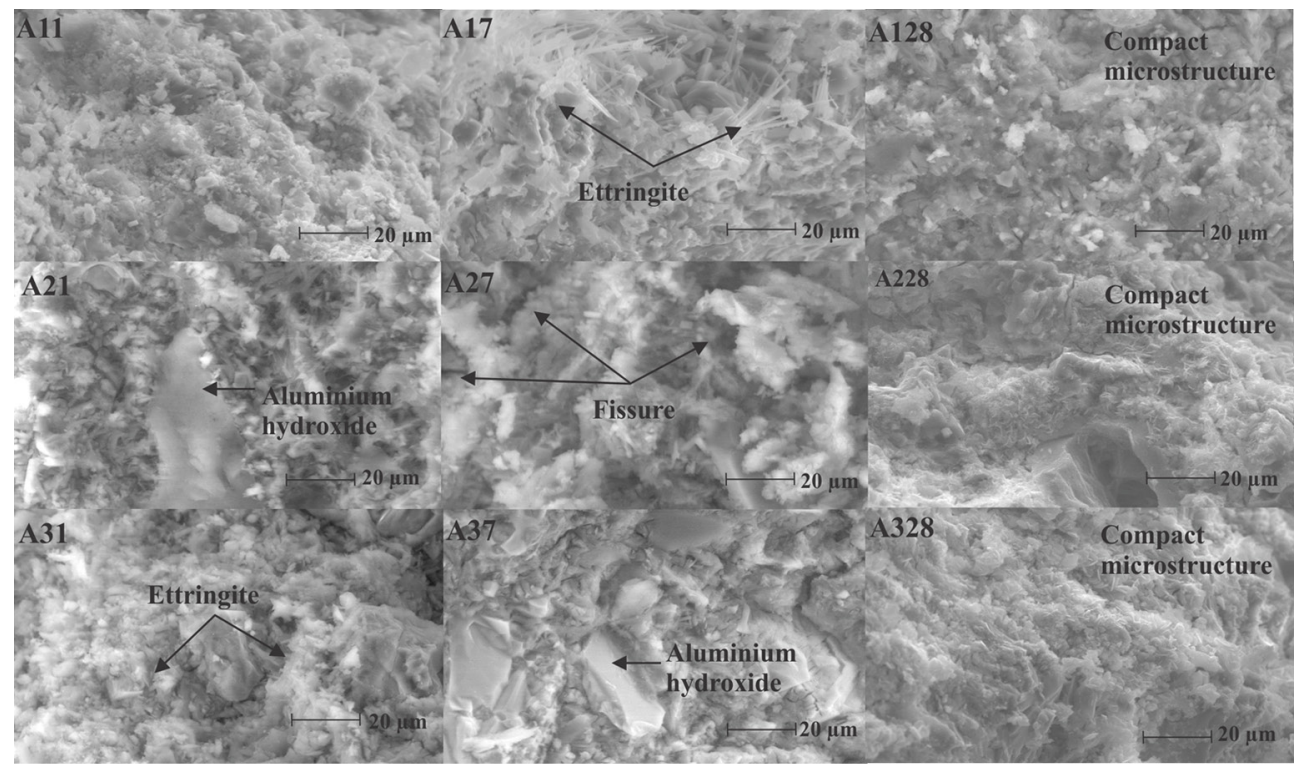

$\mathrm{A} 1, \mathrm{~A} 2, \mathrm{~A} 3$ have the same composition with $45.53 \mathrm{wt} \%$ of $\mathrm{AD}, 12.82 \mathrm{wt} \%$ of $\mathrm{FY}, 0.65 \mathrm{wt} \%$ of $\mathrm{FA}$ and 41.00 wt $\%$ of $\mathrm{CaCO}_{3}$.

Figure 4. Fracture SEM images for samples A1, A2 and A3, cured for 1,7 and 28 days at $20{ }^{\circ} \mathrm{C}$ Identification example: A17 corresponds to the system A1 cured at 7 days. 


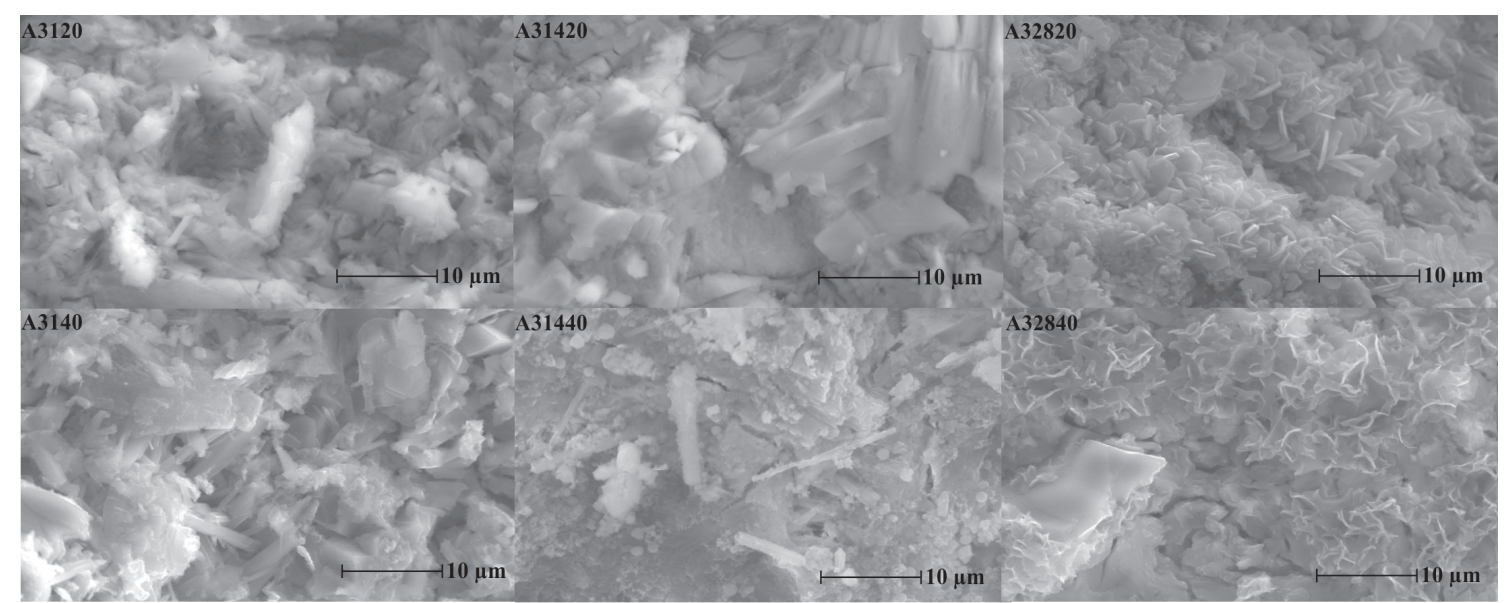

A3 has a composition de 45.53 wt $\%$ of $A D, 12.82$ wt $\%$ of $\mathrm{FY}, 0.65$ wt $\%$ of $F A$ and $41.00 \mathrm{wt} \%$ of $\mathrm{CaCO}_{3}$.

FIgURE 5. Fracture SEM images of the system A3 cured for 1,14 and 28 days at 20 or $40^{\circ} \mathrm{C}$. Identification example: A3120 corresponds to the system A3 cured for 1 day at $20^{\circ} \mathrm{C}$.

As the curing time was increased, ettringite filled the cracks showing a compact structure and increasing the compressive strength.

- The system synthesized at high temperature and cured at $20^{\circ} \mathrm{C}$ showed no decreasse in compressive strength at any curing time due to the early ettringite formation.

\section{REFERENCES}

1. Ibarra-Castro, M.N.; Almanza-Robles, J.M.; CortésHernández, D.A.; Escobedo-Bocardo, J.C.; Torres-Torres, J. (2009) Development of mullite/zirconia composites from a mixture of aluminum dross and zircon. Ceramics International. 35 [2], 921-924. http://dx.doi.org/10.1016/j. ceramint.2008.03.006

2. Kevorkijan, V.M. (1999) The quality of aluminum dross particles and cost-effective reinforcement for structural aluminum-based composites. Composites Sci. Tech. 59 [11], 1745-1751.http://dx.doi.org/10.1016/S0266-3538(99)00034-2.

3. Hashishin, T.; Kodera, Y.; Yamamoto, T.; Ohyanagy. (2004) Synthesis of $(\mathrm{Mg}, \mathrm{Si}) \mathrm{Al}_{2} \mathrm{O}_{4}$ spinel from aluminium dross. J. Am. Ceram. Soc. 87 [3], 496-499. http://dx.doi. org/10.1111/j.1551-2916.2004.00496.x.

4. Miyamoto, Y.; Kanehira, S.; Radwan, M. (2004) Recycling of industrial and natural wastes to SiAlONs. Refractories Applications and News. 9 [1], 15-16.

5. Yoshimura, H.N.; Abreu, A.P.; Molisani, A.L.; de Camargo, A.C.; Portela, J.C.S.; Narita, N.E. (2008) Evaluation of aluminum dross waste as raw material for refractories. Ceramics International. 34 [3], 581-591. http://dx.doi. org/10.1016/j.ceramint.2006.12.007.

6. Ewais, E.M.M.; Khalil, N.M.; Amin, M.S.; Ahmed, Y.M.Z.; Barakat, M.A. (2009) Utilization of aluminum sludge and aluminum slag (dross) for the manufacture of calcium aluminate cement. Ceramics International. 35 [8], 3381-3388. http://dx.doi.org/10.1016/j.ceramint.2010.03.001.

7. Murayama, N.; Maekawa, I.; Ushiro, H.; Miyoshi, T.; Shibata, J.; Valix, M. (2012) Synthesis of various layered double hydroxides using aluminum dross generated in aluminum recycling process. Intl. J. Mineral Proc. 110-111, 46-52. http://dx.doi.org/10.1016/j.minpro.2012.03.011.

8. Stegemann, J.A. (2002) The Potential role of energyfrom-waste air pollution control residues in the industrial ecology of cement. Journal of Sustainable Cement-Based Materials. 2013 [3], 111-127.
9. Damtoft, J.S.; Lukasik, J.; Herfort, D.; Sorrentino, D.; Gartner, E.M. (2008) Sustainable development and climate change initiatives. Cem. Concr. Res. 38 [2], 115-127. http:// dx.doi.org/10.1016/j.cemconres.2007.09.008.

10. Gartner, E. (2004) Industrially interesting approaches to "low-CO $\mathrm{CO}_{2}$ cements. Cem. Concr. Res. 34 [9], 1489-1498. http://dx.doi.org/10.1016/j.cemconres.2004.01.021.

11. Humphreys, K.; Mahasenan, M. (2002) Toward a sustainable cement industry. Sub-study 8: climate change, an independent study commissioned to Batelle by word business council for sustainable development. www.wbcsdcement. org.

12. Luz, C.A.; Rocha, J.C.; Cheriaf, M.; Pera, J. (2006) Use of sulfoaluminate cement and bottom ash in the solidification/stabilization of galvanic sludge. J. Hazardous Material. B136 [3], 837-845. http://dx.doi.org/10.1016/j. jhazmat.2006.01.020.

13. Older, I. (2000) Special Inorganic Cement, Library Binding, Great Britain (2000).

14. El-Didamony, H.; Heikal, M.; Khalil, Kh.A. (2013) Characteristics of cement pastes containing sulphoaluminate and belite prepared from nano-materials. Constr. Build. Mater. 38, 14-21. http://dx.doi.org/10.1016/j. conbuildmat.2012.07.098.

15. Janotka, I.; Kraji, L. (1999) An experimental study on the upgrade of sulfoaluminate-belite cement systems by blending with Portland cement. Adv. Cement Research. 11 [1], 35-41. http://dx.doi.org/10.1680/adcr.1999.11.1.35.

16. Berger, S.; Coumes, C.C.D.; Bescop, P.L.; Damidot, D. (2011) Influence of a thermal cycle at early age on the hydration of calcium sulphoaluminate cements with variable gypsum contents. Cem. Concr. Res. 41 [2], 149-160. http://dx.doi.org/10.1016/j.cemconres.2010.10.001.

17. Glasser, F.P.; Zhang, L. (2001) High-performance cement matrices based on calcium sulfoaluminate-belite compositions. Cem. Concr. Res. 31 [12], 1881-1886. http://dx.doi. org/10.1016/S0008-8846(01)00649-4.

18. Zhou, Q.; Milestone, N.B.; Hayes, M. (2006) An alternative to Portland cement for waste encapsulation - the calcium sulfoaluminate cement system. J. Hazardous Materials. 136 [1], 120-129. http://dx.doi.org/10.1016/j. jhazmat.2005.11.038.

19. Sánchez-Herrero, M.J.; Fernández-Jiménez, A.; Palomo, A. (2013) $\mathrm{C}_{4} \mathrm{~A}_{3} S$ hydration in different alkaline media. Cem. Concr. Res. 46, 41-49. http://dx.doi.org/10.1016/j. cemconres.2013.01.008

20. Qian, G.R.; Shi, J.; Cao, Y.L.; Xu, Y.F.; Chui, P.C. (2008) Properties of MSW fly ash-calcium sulfoaluminate cement 
matrix and stabilization/solidification on heavy metals. J. Hazardous Materials. 152 [1], 196-203. http://dx.doi. org/10.1016/j.jhazmat.2007.06.118.

21. Peysson, S.; Pérea, J.; Chabannet, M. (2005) Immobilization of heavy metals by calcium sulfoaluminate cement. Cem. Concr. Res. 35 [12], 2261-2270. http://dx.doi.org/10.1016/j. cemconres.2005.03.015.

22. Péra, J.; Ambroise, J.; Chabannet, M. (2004) Valorization of automotive shredder residue in building materials. Cem. Concr. Res. 34 [4], 557-562. http://dx.doi.org/10.1016/j. cemconres.2003.09.004.

23. Zhang, L.; Glasser, F.P. (2005) Investigation of the microstructure and carbonation of CSA-based concretes removed from service. Cem. Concr. Res.35 [12], 2252-2260. http://dx.doi.org/10.1016/j.cemconres.2004.08.007.

24. Pelletier-Chaignat, L.; Winnefeld, F; Lothenbach, B. Saoût, G.L.; Müller, C.J.; Famy, C. (2011) Influence of the calcium sulphate source on the hydration mechanism of Portland cement-calcium sulphoaluminate clinker-calcium sulphate binders. Cem. Concr. Comp. 33 [5], 551-561. http:// dx.doi.org/10.1016/j.cemconcomp.2011.03.005.

25. Pelletier-Chaignat, L.; Winnefeld, F.; Lothenbach, B.; Müller, C.J. (2012) Beneficial use of limestone filler with calcium sulphoaluminate cement. Constr. Build. Mater. 26 [1], 619-627. http://dx.doi.org/10.1016/j.conbuildmat. 2011.06.065.

26. García-Maté, M.; Santacruz, I.; De la Torre, Á.G.; LeónReina, L.; Aranda, M.A.G. (2012) Rheological and hydration characterization of calcium sulfoaluminate cement pastes. Cem. Concr. Comp. 34 [5], 684-691. http://dx.doi. org/10.1016/j.cemconcomp.2012.01.008.

27. Shoude, W.; Cheng, C.; Lingchao, L.; Xin, C. (2012) Effects of slag and limestone powder on the hydration and hardening process of alite-barium calcium sulphoaluminate cement. Constr. Build. Mater. 35, 227-231. http://dx.doi. org/10.1016/j.conbuildmat.2012.03.004

28. Taylor, H.F.W. (1997). Cement Chemistry, Thomas Telford, Great Britain (1997). http://dx.doi.org/10.1680/cc.25929.

29. Mehta, P.K.; Klein, A. (1965) Formation of ettringite by hydration of a system containing an anhydrous calcium sulfoaluminate. J. Am. Ceram. Soc. 48 [8], 435-436. http:// dx.doi.org/10.1111/j.1151-2916.1965.tb14786.x.

30. Taylor, H.F.W.; Famy, C.; Scrivener, K.L. (2001) Delayed ettringite formation. Cem. Concr. Res. 31 [5], 683-693. http://dx.doi.org/10.1016/S0008-8846(01)00466-5.
31. Mehta, P.K. (1967) Expansion characteristics of calcium sulfoaluminate hydrates. J. Am. Ceram. Soc. 50 [4], 204 208. http://dx.doi.org/10.1111/j.1151-2916.1967.tb15082.x.

32. Puertas, F.; Blanco Varela, M.T. (1995) Kinetics of the thermal decomposition of $\mathrm{C}_{4} \mathrm{~A}_{3} \bar{S}$ in air. Cem. Concr. Res. 25 [3], 572-580. http://dx.doi.org/10.1016/0008-8846(95) $00046-\mathrm{F}$

33. Wu, K.; Shi, H.; Guo, X. (2011) Utilization of municipal solid waste incineration fly ash for sulfoaluminate cement clinker production. Waste Management. 31 [9-10], 20012008. http://dx.doi.org/10.1016/j.wasman.2011.04.022.

34. Li, J.; Ma, H.; Zhao, H. (2007) Preparation of sulphoaluminate-alite composite mineralogical phase cement clinker from high alumina fly ash. Key Engineering Materials. 334-335, 421-424. http://dx.doi.org/10.4028/ www.scientific.net/KEM.334-335.421.

35. Li, H.; Agrawal, D.K.; Cheng, J.; Silsbee, M.R. (2001) Microwave sintering of sulphoaluminate cement with utility wastes. Cem. Concr. Res. 31 [9], 1257-1261. http:/l dx.doi.10.1016/s0008-8846(01)00579-8.

36. Singh, M.; Upadhayay, S.N.;Prasad,P.M.(1997)Preparation of iron rich cements using red mud. Cem. Concr. Res. 27 [7], 1037-1046. http://dx.doi.org/10.1016/S0008-8846 (97)00101-4

37. Singh, M.; Kapur, P.C.; Pradip. (2008) Preparation of calcium sulphoaluminate cement using fertiliser plant wastes. J. Hazardous Materials. 157 [1], 106-113. http://dx.doi. org/10.1016/j.jhazmat.2007.12.117.

38. ASTM C-204-11. (1995) Standard test methods for fineness of hydraulic cement by air permeability apparatus. West Conshohocken. annual book of ASTM Standards. Section 4. Construction. 04.01. Cement, Lime, Gypsum.

39. ASTM C-191-08 (1995) Standard test methods for time of setting of hydraulic cement by Vicat needle. West Conshohocken. Annual Book of ASTM Standards. Section 4. Construction. 04.01. Cement, Lime, Gypsum.

40. Winnefeld, F.; Lothenbach, B. (2010) Hydration of calcium sulfoaluminate cements -experimental findings and thermodynamic modelling. Cem. Concr. Res. 40 [8], 1239-1247. http://dx.doi.org/10.1016/j.cemconres.2009.08.014.

41. Xin, C.; Jun, C.; Lingchao, L.; Futian, L.; Bing, T. (2004) Study on the hydration of Ba-bearing calcium sulphoaluminate in the presence of gypsum. Cem. Concr. Res., 34 [11], 20092013. http://dx.doi.org/10.1016/j.cemconres.2004.02.021. 